\title{
THE PAROL EVIDENCE PROCESS AND STANDARDIZED AGREEMENTS UNDER THE RESTATEMENT (SECOND) OF CONTRACTS
}

\author{
John E. Murray, JR. $\dagger$
}

\section{INTRODUCTION}

One of the unassailable rudiments of contract law is that the written manifestation of assent is not the contract but merely constitutes evidence thereof. ${ }^{1}$ The scope of the "contract" may or may not be coextensive with the documentation evidencing it. ${ }^{2}$ The writing may be frugal; it may require explanation or supplementation. ${ }^{3}$ Or the writing may appear to be exhaustive and may even contain an expression that it is the final, complete, and exclusive manifestation of the parties' assent. ${ }^{4}$ Regardless of the sparsity or elaborateness of the writing, the rudiment prevails: the writing is only evidence of the contract.

The scope of the contractual obligation-the "circle of assent"-may be gleaned from sources other than the writing. ${ }^{5}$ If the writing is incomplete, the gaps are filled judicially with reasonable times, reasonable performance terms, and even reasonable prices. ${ }^{6}$ The disease of indefiniteness will now be fatal only in the extreme case in which two elements are not present: the parties' intention to be bound and a reasonably certain basis for affording a remedy. ${ }^{7}$ The augmentation of judicial gap-

† Professor of Law, University of Pittsburgh. B.S. 1955, La Salle College; J.D. 1958, Catholic University of America; S.J.D. 1959, University of Wisconsin. Member, Wisconsin Bar.

${ }^{1}$ Restatement (SeCond) of Contracts, Introductory Note \$§ 235-44, at 533 (Tent. Drafts Nos. 1-7, 1973) [hereinafter cited as Restatement (SEcond)]; J. Murray, ConTRACTS $\S 2$, at 5 (1974) [hereinafter cited as MURRAY].

${ }^{2}$ See 3 A. Corbin, Contracts $\$ 588$ (1960) [hereinafter cited as Corbin]; 4 S. Williston, Contracts $\$ 636$ (3d ed. W. Jaeger 1961) [hereinafter cited as Williston].

${ }^{3}$ See Restatement (SeCond), supra note $1, \S 240 ; 3$ Corbin, supra note $2, \S 579 ; 4$ WILLISTON, supra note $2, \S 636$.

${ }^{4}$ See 3 Corbin, supra note $2, \S 578 ; 4$ Williston, supra note $2, \S 633$.

${ }^{5}$ See 3 Corbin, supra note 2 , § 579; 4 Williston, supra note 2 , § 632.

6 See Restatement (Second), supra note 1, § 230; Uniform Commercial Code $\S \S$ $2-309,-311,-305$.

${ }^{7}$ Restatement (Second), supra note 1, § $21 \mathrm{~B}$; Uniform Commercial Code § 2-204(3). 
filling capacity dictated by article two of the Uniform Commercial Code and supported by the Restatement (Second) of Contracts is an extrapolation of a process clearly discoverable in pre-Code contract law and is, therefore, neither radical nor remarkable. ${ }^{8}$ It is a substantial recognition that parties do not always or even usually express themselves comprehensively when entering a final agreement.

Where the documentation evidencing the agreement is elaborate and perhaps even states that it is comprehensive and exclusive-the sole manifestation of the agreement-some provisions appearing in article two and incorporated in the Restatement (Second), though rooted in pre-Code contract law, are expressed without the covert devices of earlier law. The contract apparently evidenced by the complete, final, and exclusive manifestation of assent found in the writing containing, for example, the negotiated merger clause, was always subject to defenses of fraud, duress, or some form of mistake. ${ }^{9}$ Today it is also subject to the defense that one of the parties was unaware of a material risk-shifting provision inconspicuously inserted in the writing or, if aware, had no genuine choice in assenting to it. ${ }^{10}$ Because real or genuine assent was absent, a court may be called upon to excise the provision as unconscionable. ${ }^{11}$ Beyond these basic defenses, the writing may not state the true intention of the parties. If sufficient proof is introduced that the scrivener has erred, the writing will be reformed to state the true intention. ${ }^{12}$ If the writing states the true intention and the agreement is otherwise free

${ }^{8}$ Cf. Magnolia Warehouse \& Storage Co. v. Davis \& Blackwell, 108 Tex. 422, 424, 195 S.W. 184, 185 (1917):

The general rule is that parol testimony cannot be received to contradict, vary, add to, or subtract from the terms of a valid written contract. But one of the exceptions to the general rule is that if the written instrument itself shows to be either ambiguous or incomplete, parol testimony is admissible to show what the real contract was to the extent necessary to remove the ambiguity, and to make the contract complete in its terms which show to be incomplete.

See also Morgan v. Steinberg, 23 S.W.2d 527, 533 (Tex. Civ. App. 1930): "The parol evidence rule does not exclude testimony necessary to make a writing effective which on its face is clearly incomplete...."

9 See Restatement of Contracts $\& 237$ (1932); Restatement (Second), supra note 1, § 240; 3 CoRbIN, supra note 2, § 580; 4 WILLISTON, supra note 2, § 634.

${ }^{10}$ See Uniform Commercial Code $\$ \S 2-202,-207,-302$. See also Restatement (SECOND), supra note 1, § 237; Murray, Unconscionability: Unconscionability, 31 U. PITT. L. REv. 1 (1969).

11 Uniform Commercial Code § 2-302; Restatement (Second), supra note 1, § 234.

12 Restatement of Contracts $\$ 504$ (1932); 3 CoRbin, supra note 2, § 614; 4 WILLISTON, supra note $2, \S 631$. 
from the defects already mentioned, the writing is still subject to interpretation, and evidence of the meaning of the terms - evidence of the idea beneath the language skin-may be admitted to assist the courts in framing the true "circle of assent."13 (This process will occur in all jurisdictions except those that still cling to the archaic absurdity that the language has only one true and plain meaning. ${ }^{14}$ ) Interpretation will not address itself solely to the ordinary meaning of the terms; trade usage, prior course of dealing, and any evidence of partial performance under the contract will strongly indicate the meaning the parties intended by the terms of their writing. ${ }^{15}$ Even private codes or conventions between the parties may be introduced to indicate, for example, that "horse" in the writing really means "cow."16

The parties may attempt to state their agreement in clear and unambiguous words; but try as they may they will fail, for scarcely any word is capable of denoting only one thought. They may attempt to account for all contingencies, but the unforeseen may still occur. The attempt is doomed because mortals lack omniscience and presentiation is, therefore, limited. ${ }^{17}$ They may even attempt to place complete finality in their agreement by expressing that intention in their writing; but no matter, they cannot agree not to agree just as they are incapable of agreeing to agree. They can place safeguards on subsequent modifications by requiring any such modifications to be evidenced by another writing; ${ }^{18}$ but even this private statute of frauds is subject to waiver that becomes irrevocable through reliance. ${ }^{19}$

The permanent record of the agreement is created to assure certainty, stability, and predictability-to provide security to the

${ }^{13}$ See Towne v. Eisner, 245 U.S. 418, 423 (1918) (Holmes, J.): "A word is not a crystal, transparent and unchanged; it is the skin of a living thought and may vary greatly in color and content according to the circumstances and the time in which it is used."

${ }^{14}$ For recent statements of this "principle," see Kreis v. Venture Out in America, Inc., 375 F. Supp. 482 (E.D. Tenn. 1973); C \& A Constr. Co., Inc. v. Benning Constr. Co., 509 S.W.2d 302 (Ark. 1974); Fort Wayne Bank Bldg., Inc. v. Bank Bldg. \& Equip. Corp., 309 N.E.2d 464 (Ind. App. 1974).

15 UNIFORM COMMERCIAL CODE \& 2-202(a).

${ }^{16}$ See Murray, supra note 1, § 109; 3 Corbin, supra note 2, §539.

${ }^{17}$ See Macneil, Restatement (Second) of Contracts and Presentiation, 60 VA. L. Rev. 589 (1974). See also Macneil, The Many Futures of Contracts, 17 S. Cal. L. Rev. 691 (1974).

${ }^{18}$ Uniform Commercial Code \& 2-209(2).

${ }^{19}$ Id. $\S \S 2-209(4)$-(5). See, e.g., Wagner v. Graziano Constr. Co., 390 Pa. 445, 448, 136 A.2d 82, 83 (1957) (Musmanno, J.): "The most ironclad written contract can always be cut into by the acetylene torch of parol modification supported by adequate proof." See also Knight v. Gulf Ref. Co., 31 I Pa. 357, 360, I66 A. 880, 882 (1933). 
parties and to avoid the possibility of even innocent favorable recollection. ${ }^{20}$ Yet there is no writing sufficient to avoid the largely unforeseen possibilities just explored. It should, however, be possible to avoid uncertainty as to matters that are not only knowable but have been discussed prior to the execution of the final writing. As a prelude to a final agreement, any number of possibilities may have been discussed and some manifestations of tentative agreement may have occurred. Yet when the moment of final agreement arrives, evidenced by a writing that the parties intend to be the exclusive manifestation of their agreement, should they not at least be entitled to the assurance that prior discussions and even prior tentative agreements are discharged through the execution of the final, completely "integrated" writing? Certainly, if that is their intention and if they are mutually aware that the writing is the sole repository of their manifested intention, the writing should be afforded that special protection at least over prior extrinsic agreements.

Both the Code and the Restatement (Second) attempt to protect this interest in the security of agreements. The Restatement (Second) provides that "[a] binding integrated agreement discharges prior agreements to the extent that it is inconsistent with them" 21 and that "[a] binding completely integrated agreement discharges prior agreements to the extent that they are within its scope."22 Even after an integrated agreement has been proved and the prior agreement is shown to be inconsistent therewith, one can still escape the provisions of the writing by raising defenses of fraud, duress, mistake, and unconscionability. ${ }^{23}$ This Article will evaluate the effect given a writing by the Restatement (Second), beginning with an examination of its treatment of the parol evidence rule, followed by a critique of its application of the rule and of the doctrine of unconscionability to an increas-

${ }^{20}$ See E.A. Strout Western Realty Agency, Inc. v. Broderick, 522 P.2d 144, 145-46 (Utah 1974):

To permit [the introduction of oral testimony] would be to cast doubt upon all the integrity of contracts and to leave a party to a solemn agreement at the mercy of the uncertainties of oral testimony given by one who in the subsequent light of events discovers that he made a bad bargain.

See also McCormick, The Parol Evidence Rule as a Procedural Device for Control of the Jury, 41 YALE L.J. 365, 368 (1932) (exploring the possibility of "recollection warped by selfinterest").

${ }^{21}$ Restatement (SECOND), supra note $1, \S 239(1)$.

22 Id. \$ 239(2).

${ }^{23}$ See text accompanying notes 9-11 supra. 
ingly important type of contract-the standardized form contract.

\section{The Parol Evidence Process IN THE RESTATEMENT (SECOND)}

\section{A. Origins of the Parol Evidence Rule}

It can be argued that the parties' legitimate interest in the security of their agreement is adequately protected by another rudiment of contract law: parties may agree today to rescind or modify their agreement of yesterday. ${ }^{24}$ In other words, they may agree today to treat any prior agreements as nullities, and their intention should be effected. But one of the parties typically argues that the writing was not intended to nullify a particular prior agreement. He seeks to introduce evidence that such a prior agreement was made and that the parties intended it to coexist with the agreement manifested in the writing. ${ }^{25}$ Why not permit such evidence to be considered by the trier of fact? The question scarcely survives the asking. Will the trier of fact accord the writing-the permanent record of the agreement that the parties carefully framed-the preference it deserves, or will the final, written evidence of agreement be commingled with evidence of all prior discussions from which a contract may be created by the trier of fact? Certainly it can be argued that juries must not be permitted such leeway because they are not sufficiently sophisticated to accord the written evidence its sacred place. Simply put, juries may not be trusted with such a task, regardless of awesome instructions from the court, ${ }^{26}$ but must be shielded from evidence of any prior agreements if the parties indeed intended the writing to be the final and complete manifestation of their agreement. The security and stability of transactions demand this protection. On the other hand, juries must not be told that they cannot be trusted with this task or with a determination of whether the parties intended their writing to be final and complete (admittedly a question of fact) because that determination requires that evidence of the alleged prior extrinsic matter be considered and compared with the writing. Presumably no writing is sufficient to exclude evidence of every

\footnotetext{
243 Corbin, supra note $2, \S 574$.

${ }^{25}$ See, e.g., Mitchill v. Lath, 247 N.Y. 377, 160 N.E. 646 (1928).

${ }^{26}$ See McCormick, supra note 20.
} 
alleged extrinsic agreement. ${ }^{27}$ Thus a question of intention-a question of fact-must be kept from the jury. That question of intention must be reserved for the court and may even be characterized as that which it is not-that is, a question of law-to insure that the court will decide it. ${ }^{28}$

Because the goal has been defined as precluding the jury from even hearing the evidence of the prior agreement, the court's ultimate finding that the writing is final and complete is properly characterized as an evidentiary process. Typically the evidence of the prior extrinsic matter sought to be introduced will be evidence of a parol (which often means "oral") agreement. Thus the process by which the court decides whether to permit the trier of fact to hear evidence of the prior extrinsic agreement may be called the application of the parol evidence rule. Under such a caption the process may appear to be just another judicial evidentiary ruling, and the unpleasantness of informing juries of their incapacity to deal with a question of intention may be avoided. ${ }^{29}$

Other difficulties remain. How will the court itself determine whether the parties intended their writing to be complete and final-that is, totally integrated-thereby evidencing their intention that any alleged prior agreement was to be nullified? Shall the court first determine whether the prior agreement was in fact made? This is a matter of intention-clearly a question of fact. That the parties made such an agreement prior to their writing does not mean they intended it to survive execution of the writing. Moreover, if the court is convinced that the parties did make the prior agreement, then even the court may not accord the final writing the preference it deserves. ${ }^{30}$ Therefore, the test for integration must be different: if parties situated as were these would naturally and normally include the matter of

${ }^{27}$ RESTATEMENT (SECOND), supra note $1, \S 236$, comment $b$.

${ }^{28}$ For a recent example, see Storybook Homes, Inc. v. Carlson, 19 Ill. App.3d 579, 312 N.E.2d 27 (1974).

${ }^{29}$ See McCormick, supra note 20, at 369:

"Parol evidence is inadmissible to vary, contradict, or add to the terms of a written instrument." The phrase becomes a shibboleth, repeated in ten thousand cases. It obviously enables the judge to head off the difficulty at its source, not by professing to decide any question as to the credibility of the asserted oral variation, but by professing to exclude the evidence from the jury altogether because forbidden by a mysterious legal ban.

${ }^{30} \mathrm{Cf}$. Geiger v. Hansen, 214 Kan. 83, 519 P.2d 699 (1974) (admitting evidence of the prior agreement, which the court believed was made, under the guise of a condition). 
their extrinsic agreement in the writing subsequently executed, the extrinsic matter will be regarded as a nullity because that is their presumable intention. ${ }^{31}$ This presumable intention may be fictitious but it is necessary in order to maintain the sanctity of the writing. If the extrinsic matter may naturally and normally coexist with the writing subsequently executed, evidence of such extrinsic matter may be laid before the trier of fact, who may then decide whether the evidence is sufficient to support a finding that such an agreement was made. Another guide (rather than test) is suggested: was the extrinsic matter mentioned or dealt with at all in the writing? If it was mentioned in the writing, then presumably the parties have expressed all of their intention as to that matter in the writing and do not intend to be bound by any prior agreement with respect to that matter. If the matter is not mentioned or dealt with at all in the writing, then presumably the parties did not intend their writing to nullify any such prior agreement. ${ }^{32}$

Some commentators strongly urge a test that would emphasize the actual intention of the parties. They would eschew any evidentiary gloss and have the court focus upon two questions: Was the extrinsic agreement made? Did the parties intend to nullify that agreement by their subsequent writing? ${ }^{33}$ This merely restates the principle mentioned above: Did the parties agree today to nullify their agreement of yesterday? The application of this test requires no "parol evidence rule." It emphasizes the actual intention of the parties rather than the fictitious problem of whether parties might naturally and normally include the alleged extrinsic matter in the writing.

The chief proponent of the actual intention test was Professor Corbin. ${ }^{34}$ It is generally agreed that the Corbin view emasculates the parol evidence rule. ${ }^{35}$ The chief proponent of the fictitious intention test, Professor Williston, was extremely anxious to protect the integrity of the writing over inferior, antecedent expressions of agreement. ${ }^{36}$ Because both giants of contract law described the critical question to be decided by the court as one

${ }^{31}$ See, e.g., Uniform Commercial Code $\S 2-202$, Comment $3 ; 4$ Williston, supra note $2, \S 633$.

${ }^{32}$ See 9 J. Wigmore, Evidence $\$ 638$ (3d ed. 1940) [hereinafter cited as Wigmore].

${ }^{33} 3$ CoRBN, supra note $2, \S 582$.

${ }^{34}$ Id.

3547 ALI Proceedings 476 (1970).

${ }^{36} 4$ Williston, supra note 2 , \& 638. 
of the intention of the parties, a discussion of their complete disagreement as to how this process is to be made operative has often been avoided. Many desirable and highly readable analyses of the parol evidence rule attempt to clarify the process by, inter alia, distinguishing it from questions of mistake, fraud, duress, unconscionability, reformation, interpretation, and even conditions precedent to contract formation. ${ }^{37}$ Less attention has been paid to the process of the trial court's determination of integration. The term "integration" itself is a conclusory label with the appearance of considerable analytical meaning, but it can be applied only after the analysis is complete. With rare exceptions, however, judicial grappling with parol evidence questions demonstrates considerable myopia. ${ }^{38}$ A typical judicial effort involves no more than application of conclusory labels-for example, that the extrinsic matter is "collateral" to the agreement manifested by the writing-without the analysis necessary to a proper determination of integration. ${ }^{39}$

With the appearance and now almost universal enactment of article two of the Uniform Commercial Code, with its total rejection of a property orientation for sale-of-goods contracts ${ }^{40}$ and its almost iconoclastic emphasis on "agreements in fact" and consequent de-emphasis of the written manifestation of agreement (particularly printed forms), ${ }^{41}$ one might have expected that a major restatement of the parol evidence rule would be included. For critics of the rule, the Code restatement is a disappointment. ${ }^{42}$ The hopes of the critics were again raised with the appearance of the Restatement (Second) of Contracts, which largely incorporates the substantial modifications of traditional

${ }^{37}$ See, e.g., Calamari \& Perillo, A Plea for a Uniform Parol Evidence Rule and Principles of Contract Interpretation, 42 IND. L. Rev. 333 (1967); Sweet, Contract Making and Parol Eridence: Diagnosis and Treatment of a Sick Rule, 53 CoRnell. L. Rev. 1036 (1968).

${ }^{38}$ For one of the rare exceptions, see the majority opinion in Masterson v. Sine, 68 Cal.2d 222, 436 P.2d 561, 65 Cal. Rptr. 545 (1968).

${ }^{39}$ See, e.g., Pasquale Food Co. v. L \& H Int'l Airmotive, Inc., 51 Ala. App. 127, 134, 283 So. 2 d 438, 444 (1973):

The comparison is made with certain established tests applied to the oral agreement: (I) Is it in form a collateral one? (2) It must not contradict express or implied provisions of the written contract. (3) It must be one that parties would not ordinarily be expected to embody in the writing.

Cf. Intermar, Inc. v. Atlantic Richfield Co., 364 F. Supp. 82, 98 (E.D. Pa. 1973); Jannes v. Microwave Communications, Inc., 16 Ill. App.3d 582, 588, 306 N.E.2d 473, 478 (1973);

Young v. Gardner, 507 S.W.2d 250, 261-62 (Tex. Civ. App. 1974).

40 Uniform Commercial Code $\$ 2-401$, Preamble; id. \$ 2-509, Comment 1 .

${ }^{41}$ See id. $\S \S 1-201(3), 2-207$.

${ }^{42}$ Cf. id. $\S 2-202$. 
contract doctrine found in article two of the Code and often extrapolates Code changes in the American realist tradition. ${ }^{43}$ Moreover, the Restatement (Second) is clearly influenced by the criticisms of Professor Corbin, whose extensive notes-though still secreted in the possession of the Chief Reporter-were available to the draftsmen of the Restatement (Second). ${ }^{44}$

Whether the hopes of the rule's critics were dashed again is one of the subjects of this Article. If the Restatement (Second) manages to set forth a statement of the rule and its appendages that courts can adopt and apply, the confusion and contradiction evidenced by judicial attempts to apply some kind of parol evidence rule may be remedied. The original Restatement of Contracts and, presumably, the Restatement (Second), are presented as authoritative expositions of the subject; but an authoritative exposition of the cluster of concepts labeled the "parol evidence rule" is no easy task. It is important to determine whether that task has been accomplished.

\section{B. The "Preliminary" Determination}

If one searches the Restatement (Second) to discover the section dealing with the parol evidence rule, it may appear to be section 239, captioned parenthetically "Parol Evidence Rule." Yet the title of section 239, to which the parenthetical was belatedly added, is "Effect of Integrated Agreement on Prior Agreements." Thus the Restatement (Second) describes the parol evidence rule in terms of "effect." It might also be described as an inevitable conclusion; and, like other conclusory statements, its analytical value is suspect. In particular, subsections (1) and (2) of section 239 contain all of the qualities of a truism:

(1) A binding integrated agreement discharges prior agreements to the extent that it is inconsistent with them.

(2) A binding completely integrated agreement discharges prior agreements to the extent that they are within its scope. ${ }^{45}$

Comment $b$, entitled "Inconsistent terms," begins to suggest the critical question: "Whether a binding agreement is completely integrated or partially integrated, it supersedes inconsis-

\footnotetext{
${ }^{43}$ See Murray, The Realism of Behaviorism Under the Uniform Commercial Code, 51 ORE.

L. REv. 269 (1972).

4448 ALi Proceedings 442 (1971).

${ }^{45}$ Restatement (SeCOND), supra note $1, \S 239$.
} 
tent terms of prior agreements. To apply this rule, the court must make preliminary determinations that there is an integrated agreement and that it is inconsistent with the term in question." 46

The "preliminary determinations" of "integration" are the subject of sections 235 and 236, the first two sections of topic three, "Effect of Adoption of a Writing." Section 235 identifies an "Integrated Agreement" as one or more writings "constituting a final expression of one or more terms of an agreement" 47 and states that the question of integration is a question for the court "preliminary to determination of a question of interpretation or to application of the parol evidence rule."48 Section 236, "Partially Integrated Agreements," distinguishes completely integrated from partially integrated agreements ${ }^{49}$ and likewise indicates that the question of either complete or partial integration is one for the court "as a question preliminary to determination of a question of interpretation or to application of the parol evidence rule." 50 Section 239 states the effects of the determination that the "agreement" is integrated. ${ }^{51}$ Section 240 lists some well known exceptions to the rule that an integrated agreement supersedes prior statements. ${ }^{52}$ Section 241 indicates that evidence may not be admitted to contradict the terms of an integrated writing whether the writing is partially or completely integrated..$^{53}$ With unassailable logic, section 242 states that the evidence of consistent additional terms is inadmissible if the writing is deemed by the court to be completely integrated.$^{54}$ Subsection (2) of section 242 proceeds to suggest two tests for complete integration not found in section 236.

The critical question-arguably the exclusive questioninvolved in the parol evidence process is the question of integration. It is a "preliminary" question only in the sense that it must be answered in the negative by the court before the additional terms may be considered by the jury. It is, however, the only question that the court must consider. The essence of the

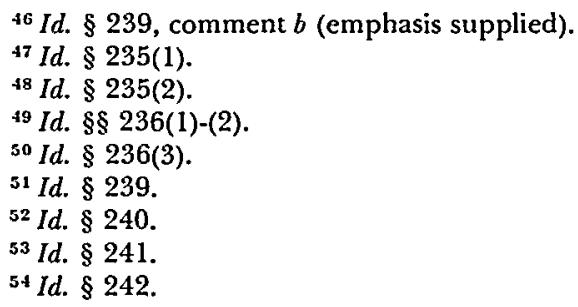


parol evidence process is found in the determination of the parties' intention that their writing be the final expression of their agreement. The further determination that the parties intended their writing to be complete as well as final renders their writing not only integrated but "completely integrated." 55 If a writing is completely integrated, the intention of the parties has been determined to be that the writing is the complete, final, and exclusive manifestation of their agreement. The negative implication is obvious: no prior agreement relating to matters within the scope of their contract was intended by the parties to be binding, even if such a prior agreement is consistent with the terms of their exclusive statement. Having decided that the parties intended their writing to be the exclusive statement of their mutual undertakings, a court will protect that intention by refusing to enforce prior agreements. ${ }^{56}$ Thus the parol evidence "rule"-or, preferably, the parol evidence "process"-is itself the determination of integration by the court. It is not the preliminary question; it is the only question. From this perspective, the parenthetical phrase "Parol Evidence Rule" might more properly have been added to the sections on integration, sections 235 and 236.

The foregoing should not be dismissed as a matter of semantics. A curious myopia has prevailed among lawyers and judges as to the process called the parol evidence rule. Unfortunately, the Restatement (Second) may not only fail to remedy, but may actually help to perpetuate that defect. The American Law Institute Proceedings contain only a perfunctory discussion of the critical question of integration in sections 235 and 236, though the Chief Reporter was obviously willing to entertain greater discussion of the matter. ${ }^{57}$ Section 237, dealing with standardized agreements, had been extensively explored in connection with the new section on unconscionability, section 234; and after the brief mention of sections 235 and 236, the members went on to section 238, "Interpretation of Integrated Agreements." This discussion consumed the rest of the time de-

$55 I d . \S 236$.

${ }^{56}$ See, e.g., La Puzza v. Prom Town House Motor Inn, Inc., 191 Neb. 687, 691, 217 N.W.2d 472, 476 (1974) ("Any such agreement should have been included in the terms of the contract if it was to be effective. Defendant is now seeking to reform the contract by parol evidence, asserting an agreement which allegedly was made before the contract was signed."); accord, Lamb v. Bangart, 525 P.2d 602, 607 (Utah 1974).

5747 ALI Proceedings 536-37 (1970). 
voted to the Restatement (Second) of Contracts in the 1970 Proceedings. With only two minutes remaining, the Director said, "I think it would be foolhardy to believe that the Reporter could dispose of the parol evidence rule in two minutes . . .," thus indicating that the questions discussed to that point, including the questions of integrated agreements, were regarded as separate from, and preliminary to, the parol evidence rule. ${ }^{58}$

With the exception of section 238, however, all the sections of topic three are certainly related to the parol evidence rule. By identifying the rule as "primarily" stated in section 239, emphasis is placed upon the effect of the rule or, again, the necessary conclusion from a finding of integration, rather than upon the critical question of how a court decides whether the parties intended their writing to be a final, or a final and complete, expression of their agreement. This bifurcation of a single process allows a court to attach a conclusory label_-"integrated" or "completely integrated"- to a particular contract and then to "apply" the parol evidence "rule" to exclude evidence of prior statements without focusing on the fundamental question of whether the evidence should be admitted. By perpetuating this confusion, the Restatement (Second) largely negates the beneficial effects of its adopting Corbin's more realistic view of the parol evidence process.

\section{Integrated Agreements and Integrated Writings}

The definitions in sections 235 and 236 cause some concern because of their possible confusion of the agreement with the writing. Any written expression of the agreement-whether it is not final, final, or final and complete-is nothing more than the manifestation of the agreement. It is not the agreement. ${ }^{59}$ If the expression of agreement is determined to be final and complete, the terms of the agreement will be regarded as only those terms set forth in the writing. Two forms of intention must be distinguished if any attempt to understand the parol evidence process is to be successful. In order to have any binding agreement, the parties must intend to be bound to certain obligations they have

${ }^{58}$ Id. 544. In his opening remarks in 1971 , the Reporter, in discussing a suggestion that the caption for the whole of topic three should include a reference to the parol evidence rule, claimed that "the parol evidence rule is primarily stated in section 239 ...." 48 id. 445 (1971).

${ }^{59}$ See text accompanying note 1 supra. 
voluntarily undertaken. ${ }^{60}$ This intention, tested through its outward manifestations because a subjective test is unworkable, ${ }^{61}$ is a sine qua non of an enforceable agreement. The parol evidence process, on the other hand, is concerned with a different intention, the intention to be bound exclusively to those undertakings evidenced by a writing or writings. The sine qua non for the invocation of the parol evidence process is that the parties have expressed their agreement in the form of a writing. The focus then shifts to whether they intended that writing to be their final expression of agreement, their complete expression of agreement, or only some incomplete expression thereof.

The confusion between the agreement and the writing is found throughout the Restatement (Second) sections that bear upon the parol evidence process. After defining "integrated agreement" as a writing or writings constituting a final expression of one or more terms of the agreement and a "completely integrated agreement" as a complete and exclusive statement of the terms of the agreement, section 239 indicates that "[a] binding integrated agreement discharges prior agreements to the extent that it is inconsistent with them."62 Is "it" the agreement or the writing evidencing the agreement?" Because "integrated agreement" is defined in section 235 as "a writing or writings constituting a final expression," it may be inferred that "it" refers to the writing. However, this plausible analysis is overcome by section 241, concerning contradiction of integrated terms: "Except as stated in the preceding section [exceptions to the parol evidence rule], where there is a binding agreement, either completely or partially integrated, evidence of prior or contemporaneous agreements or negotiations is not admissible in evidence to contradict a term of the writing." 64

Why is "writing" used in section 241 rather than "integrated agreement," which, after all, is defined as "a writing or writings constituting a final expression"? ${ }^{65}$ Some assistance may be derived from comment $a$ to section 241, which indicates that the rule of section 241 is simply "an evidentiary consequence of $\S 239$." Although this is less than completely satisfactory, it might

\footnotetext{
60 See text accompanying note 7 supra.

61 See Murray, supra note $1, \S 19$.

62 Restatement (Second), supra note 1, § 239(1) (emphasis supplied).

${ }^{63}$ Cf. id. $\$ 239$.

${ }^{64}$ Id. $\S 241$ (emphasis supplied).

${ }^{65} I d . \S 235$.
} 
be plausible to view section 239 as stating the substantive effect of the parol evidence rule-that is, the discharge of prior agreements-while section 241 , which deals with the inadmissibility of evidence to contradict a term of the writing, is viewed as a procedural consequence of the determination that the agreement is integrated. Even this reading is doomed, however, when section 242, concerning consistent additional terms, is considered. Like section 241 , it merely "states an evidentiary consequence of $\S 239 . " 66$ Section 242(1) provides, "[e]vidence of a consistent additional term is admissible to supplement an integrated agreement unless the court finds that the agreement was completely integrated." A reasonable paraphrase of this subsection might be: evidence of consistent additional (prior?) terms is inadmissible to supplement the terms of a completely integrated agreement. Why not "writing," as in section 241, rather than "agreement"?

It should be emphasized that the Reporter seemed less than enamored of the continued use of "integrated" in any form ${ }^{67}$ and at one point suggested, "I think there is a certain sorrow about the phrase 'integrated agreement' and if you had a better word, it could well be an improvement." 68 No "better word" emerged from the discussions, so the phrase remained; unfortunately, it is not sufficiently distinguished from the more cogent if still conclusory phrase, "integrated writing."

The language and structure of these sections reveal little awareness of the supreme importance of the underlying question: did the parties intend their writing to be a final or final and complete expression of their agreement? The corollary question of how the court, to which the matter has been left by the $R e$ statement (Second), ${ }^{69}$ decides whether the parties intended their writing to be a final or final and complete expression of their agreement is, therefore, equally underemphasized. The discoverable terms are usually found in the comments, which contain parts of the Corbin, Williston, and Wigmore tests, ${ }^{70}$ some slight mention of the "appearance" test, ${ }^{71}$ and a provision concerning

${ }^{66}$ Id. $\$ 242$, comment $a$.

67 48 ALI Proceedings 444-46 (1971).

68 Id. 446.

${ }^{69}$ See Restatement (SECond), supra note $1, \S 239$, comment $b$.

${ }^{70}$ See generally 3 CoRBIN, supra note $2, \S \S 573-96 ; 9$ WIGMORE, supra note 32 , $\S$ 2429-49; 4 WILLISTON, supra note 2 , §§ 631-47.

71 Restatement (SECOND), supra note $1, \S 236$, comment $b$. 
consistent additional agreements for a separate consideration. ${ }^{72}$ But there is no single section or comment addressed to this ultimate question. Hints as to how a court should go about deciding this question of intention are strewn haphazardly throughout topic three, but there is virtually no consideration of the question in the Proceedings. The question may be repressed but it will not disappear. After the discussion had long passed the question of integration as recorded in the 1971 Proceedings, a member still wondered, "[H]ow do you get something integrated?"73 This question can only be answered by analyzing how a court will decide whether the parties intended their writing to be final or final and complete-or, to use the established terminology, how a court will decide whether the writing is (completely or partially) integrated. The Restatement (Second) contains several guides to aid courts in this effort.

\section{Deciding the Question of "Integration"}

I had started with the original formulation in the First Restatement, and with Professor Corbin's notes which left very little of the parol evidence rule, and took, I think, a ground that went somewhat short of what Professor Corbin would have liked. I took my lead in this draft largely from the section of the Uniform Commercial Code which deals with the parol evidence rule [section 2-202] as it applies to contracts for the sale of goods. ${ }^{74}$

From these remarks by the Reporter, one might expect to discover in the Restatement (Second) a position moving away from the original Restatement's Williston position ${ }^{75}$ but still falling short of Corbin's virtual emasculation of the "rule" 66 and somewhat influenced by the U.C.C. formulation. ${ }^{77}$ It is interesting to compare this drafting intention with the end product, particularly in relation to the critical question of how a court determines whether the parties intended their writing to be final or final and complete.

\footnotetext{
$72 I d . \S 242(2)$

i3 48 ALI Proceedings 452 (1971).

is Id. 442.

${ }^{75}$ Restatement of Contracts \$ 237 (1932); see 4 Williston, supra note 2 , § 638 .

76 Corbin, supra note $2, \S 573$.

"7 UNiform Commercial Code $\$ 2-202$.
} 


\section{Proof of Integration in General}

The first indication of the test suggested in the Restatement (Second) is found in comment $c$ to the first section of topic three, section 235: "Whether a writing has been adopted as an integrated agreement is a question of fact to be determined in accordance with all relevant evidence." That the question is "one of fact" has long been generally conceded. ${ }^{78}$ The significance of the statement is its direction that the integration determination be made "in accordance with all relevant evidence." The flavor of Corbin is here so strong as to mask any others. Professor Corbin has suggested that "[o]n this issue of fact, no relevant testimony should be excluded."79 Here, at the outset of the Restatement (Second), Corbin appears to win the first and probably the decisive battle. Corbin emphatically insisted that a determination of "intention to integrate" is a question of fact to be decided by the actual intention of the parties. ${ }^{80}$ Williston would have none of this:

$[\mathrm{I}] \mathrm{f}$ the court may seek this intention from extrinsic circumstances, the very fact that the parties made a contemporaneous oral agreement will of itself prove that they did not intend the writing to be a complete memorial. The only question open would be whether such a contemporaneous oral agreement was in fact made. ${ }^{\mathbf{8 1}}$

Williston had visions of this question-whether the oral agreement was in fact made-being submitted to the jury, thereby destroying the parol evidence rule. The underpinnings of the rule-the sanctity of writings and the lack of juror sophistication-would thus be uprooted. ${ }^{82}$ Corbin, however, placed the burden on the proponent of the antecedent expression of agreement to prove both the fact that such an agreement was made and that the parties did not intend their subsequent writing to discharge the antecedent agreement. ${ }^{83}$ He recognized that this burden would probably not be sustained in cases where the writing appeared to be a complete and accurate expression

\footnotetext{
${ }^{78} 3$ CoRBIN, supra note $2, \S 576$, at $382 ; 4$ WILIISTON, supra note $2, \S 633$, at 1014 .

793 CoRBIN, supra note $2, \S 582$, at 455 .

${ }^{80} \mathrm{Id}$. $\$ 582$, at $456-57$.

814 WiLListon, supra note $2, \S 633$, at 1014 (footnote omitted).

${ }^{82} \mathrm{Id}$. $\$ 631$, at 958-63.

833 CoRBIN, supra note $2, \S 582$, at 457 .
} 
of the agreement. In such cases, courts would typically find the offered testimony "so flimsy and improbable as to justify a directed verdict." 84 Yet, he insisted, the party denying integration should be given the opportunity to show that the evidence as to both questions was not "flimsy or improbable." The party

must have respectable evidence to show that the antecedent agreement or expression that he alleges did in fact exist, and also to show that it has not been discharged or nullified by a new agreement-that is, that the writing produced in court was not assented to as a complete and accurate integration of a substituted agreement. ${ }^{85}$

While the Restatement (Second) is clearly Corbin-oriented in permitting "all relevant evidence" to determine the factual question whether the writing has been adopted as a final expression of the agreement, ${ }^{86}$ it does not clearly indicate the relevance of whether the antecedent agreement was in fact made. The comment language is curious: "Whether a writing has been adopted as an integrated agreement is a question of fact to be determined in accordance with all relevant evidence. The issue is distinct from the issues of whether an agreement was made and whether the document is genuine ...."87

As used in the second sentence, "an agreement" would refer to the "integrated agreement" of the first sentence. Therefore, the distinction suggested is between the issue whether there was any agreement and the issue whether, assuming such an agreement was in fact made, it was an integrated agreement. Proof of the antecedent agreement presumably would be included in the category of "all relevant evidence," because of the clear Corbin orientation; it is unrealistic to assume that a court could effectively deal with only the second question-whether the parties intended their written expression to discharge the prior agreement-if there was no respectable evidence of a prior agreement. The Restatement (Second) accurately reflects the case law in insisting that the question whether the antecedent agreement was made has no relevance to the determination of

\footnotetext{
${ }^{84} I d$. (footnote omitted).

${ }^{85} I d$. (footnote omitted).

${ }^{86}$ RestateMent (SECOND), supra note $1, \$ 235$, comment $c$.

${ }^{87}$ Id.
} 
integration; ${ }^{88}$ the former question should be one for the trier of fact and should not be reserved to the trial judge.

It would have been desirable for the Restatement (Second) to deal with the relevancy of determining the existence of the antecedent agreement. This omission requires that the critical test of integration be a factual determination of whether a writing has been adopted as a final expression of the parties' agreement, based on all the relevant evidence. Such evidence includes proof that an agreement antecedent to the writing was in fact made and that the parties did not intend their written expression of agreement to discharge the prior agreement. If the burden of proof as to these two questions is sustained, the writing will not be deemed integrated. As to whether the agreement manifested by an integrated writing was in fact made, that issue remains for the trier of fact and is irrelevant to the determination of integration. This test assumes a Corbin position as to the relevancy of determining whether the antecedent agreement was in fact made $^{89}$ and, in the interests of clarity, distinguishes between the integrated writing and the agreement that such writing manifests.

Section 236 of the Restatement (Second) distinguishes between completely and partially integrated agreements. If the writing is final as to some matters, it is integrated as to those matters-that is, it is partially integrated. If the writing is final as to all matters, it is completely integrated. The test for determining partial versus complete integration is stated in almost the identical language of the section 235 test-whether "a writing was or was not adopted as a completely integrated agreement may be proved by any relevant evidence." 90 The only difference between sections 235 and 236 is the insignificant distinction between "all" in section 235 and "any" in section 236.

Section 235(2) unambiguously declares that the question of integration is one for the court-a change from the original Restatement. ${ }^{91}$ The comment, however, states that "[o]rdinarily the issue whether there is an integrated agreement is determined by the trial judge . . . "92 The qualification is closer to the Corbin

${ }^{88}$ See 3 Corbin, supra note $2, \S 582$, at 448 n.78 and cases cited therein.

${ }^{89} \mathrm{Id}$. $\$ 582$.

${ }^{90}$ Restatement (Second), supra note $1, \S 236$, comment $b$ (emphasis supplied).

91 Restatement of Contracts $\$ 228$ (1932).

92 Restatement (Second), supra note $1, \S 235$, comment $c$. 
position. Corbin believed that, in most cases, it is probably "wise" for the court to decide this issue of fact; but he hastened to add that there must be many cases in which the evidence "is so nearly equal in weight and credibility that the court will desire the aid of a jury's verdict. If so, there is no law against getting such aid." 93

\section{The Appearance Test}

Williston believed that the parties may expressly provide that the agreement is integrated (in a merger clause, for example) and that their expressed intention should be effectuated. ${ }^{94}$ Corbin, on the other hand, urged that even in such a case, recognizing that the form and wording of the writing could be decisive, the party denying the integration should always be given the opportunity to show that the parties had not assented to the writing as a complete integration. ${ }^{95}$ The Restatement (Second) recognizes the "appearance" test in section 235(3), stating that a written agreement which appears to be complete and specific may be determined to be integrated, permitting, however, contrary evidence to establish that the parties did not intend the writing to be their final expression. ${ }^{96}$ In section 236 , "Completely and Partially Integrated Agreements," there is a further repudiation of the Williston approach and a clear adoption of the Corbin (and Wigmore) view that although a writing apparently complete on its face may be decisive of the issue, credible contrary evidence may be introduced to negate such a finding. ${ }^{97}$ Wigmore's view is particularly evidenced by the statement that "a writing cannot of itself prove its own completeness," 98 a position warmly supported by Corbin. This is quickly followed by the Corbin philosophy: "[W]ide latitude must be allowed for inquiry into circumstances bearing on the intention of the parties." 99

There is at this point no mention of "merger" clauses. A comment to section 242, "Consistent Additional Terms," indicates that such a clause "if agreed to is likely to conclude the

\footnotetext{
93 3 CoRBIs, supra note $2, \S 595$, at 571 .

944 WILliston, supra note $2, \S 633$, at 1014 .

953 CoRBIN, supra note $2, \S 582$, at 456-57.

96 Restatement (SECOND), supra note 1 , $\$$ 235-36.

97 Id. $\$ 236$, comment $b ; 9$ WIGMORE, supra note $32, \S 2430$, at 98 .

98 Restatement (SECOND), supra note $1, \S 236$, comment $b$.

${ }^{99}$ Id.
} 
issue whether the agreement is completely integrated."100 The phrase "if agreed to" could be directed toward a distinction between a negotiated merger clause and a printed merger clause as part of a standardized form; it is unfortunate that this distinction can only be inferred from the phrase. The question might well have been considered in relation to section 237, "Standardized Agreements"; the absence of any mention of merger clauses in section 237 tends to negate the distinction, however.

The remainder of the merger clause comment in section 242 is confusing: "[S] uch a clause does not control the question whether the writing was assented to as an integrated agreement ...."101 The Reporter's Note directs attention to the Corbin treatise, ${ }^{102}$ which contains language remarkably similar to the Restatement (Second) comment on merger clauses. ${ }^{103}$ As to the last portion of the comment just quoted, however, the relevant portion of Corbin appears to be the following: "The fact that a written document contains one of these express provisions does not prove that the document itself was ever assented to or ever became operative as a contract." 104 The Corbin position is clear: the existence in a writing of an express statement that the writing is completely integrated does not prove there is an agreement that the parties intended to be a contract. Whether they intended to have an enforceable agreement is an issue distinct from the issue of integration; if they did intend to be contractually bound, however, the express provision in the writing indicating complete integration will, if assented to, be decisive proof of the intention that their writing be a final and complete expression of their agreement. In contrast to Corbin's clarity, the $R e$ statement (Second) comment language can be read to suggest that even if a merger clause is assented to, it will not control the question whether the parties intended their writing to be integrated. It is more than probable that the comment language was not designed to produce this result; the unfortunate language appears attributable to the fundamental error, analyzed above, of not distinguishing between the agreement itself and the integrated writing that evidences it. ${ }^{105}$ As noted earlier, the Reporter




felt "sorrow" in the use of the phrase "integrated agreement" and invited suggestions for substitutes. ${ }^{106}$ It is unfortunate that none was forthcoming.

\section{The Scope Test}

\section{a. Preliminary Considerations-Terminology}

In section 239 (identified as the "primary" section dealing with the parol evidence rule ${ }^{\mathbf{1 0 7}}$ ), subsection (1) states the generally accepted effect of a finding that the writing is either partially or completely integrated: inconsistent terms of prior agreements are superseded. It is interesting that the term used is "inconsistent." ${ }^{108}$ The related section, section 241, which merely "states an evidentiary consequence of $\S 239$," uses the term "contradict," clearly intending it to be interchangeable with "inconsistent." ${ }^{109}$ Sections 239(1) and 241 may be viewed from different perspectives, one substantive and one procedural: First, a binding integrated agreement substantively discharges inconsistent prior agreements; and second, evidence of such contradictory terms will therefore not be admissible. If the synonymous use of "inconsistent" and "contradictory" constituted the only basis for a critique of sections $239(1)$ and 241, it would be a small matter. There are, however, other problems.

Section 239(1) speaks only of "prior" agreements while section 241 refers to "prior or contemporaneous agreements or negotiations." The Reporter included "or contemporaneous" at the suggestion of an unidentified member, ${ }^{110}$ explaining the original omission as follows:

I left out the "or contemporaneous" partly because Professor Corbin was so opposed to the idea, and partly because I don't know that anything is ever contemporaneous with anything else really, it either comes before or after. But it can be relatively contemporaneous, and I think what we say here is that evidence of prior or contemporaneous agreements or negotiations is not admissible in evidence to contradict the term of the

\footnotetext{
10648 ALI Proceedings 446 (1971).

${ }_{107}$ See text accompanying notes 57-58 supra.

108 Restatement (SECOND), supra note 1, § 239.

${ }^{109}$ Id. § 241.

11048 ALI Proceedings 449 (1971).
} 
writing, that is to say, show a different agreement from the one that the writing would show. ${ }^{111}$

The term having been omitted from section 239(1), its inclusion in the companion section, which merely states an evidentiary consequence of section $239(1)$, is confusing. The Reporter clearly was not enamored of the usage, stating the classic Corbin reason for his opposition. ${ }^{112}$ Perhaps this represents the overriding spirit of compromise that restatement reporters must pursue. The result, however, permits the grotesque possibility, which hopefully will never occur, that prior, but not contemporaneous, inconsistent agreements will be superseded by binding integrated agreements, while both prior and contemporaneous agreements or negotiations will be inadmissible to contradict the terms of a binding integrated agreement.

The situation worsens when the rationale for rejecting the term "vary" in the Restatement (Second) is explored. ${ }^{113}$ The Reporter's preference in section 241 for "contradict" is not a matter of great concern, and "contradict" is more precise; but his explanation is startling: "[W] hen you admit parol evidence to assist in interpretation, it seems to me that logically what you are doing is varying the meaning the agreement would have if you did not use the parol evidence to aid interpretation." ${ }^{114}$ In omitting "contemporaneous" from section 239 and in only reluctantly including it in section 241, the Reporter does not stray from the Corbin orientation found in virtually all sections of topic three. The stated rationale for the rejection of "vary," however, is diametrically opposed to one of Professor Corbin's lifetime crusades, and it is difficult to quarrel with the Corbin position:

It is sometimes said, in a case in which the written words seem plain and clear and unambiguous, that the words are not subject to interpretation or construction. One who makes this statement has of necessity already given the words an interpretation-the one that is to him plain and clear; and in making the statement he is asserting that any different interpretation is "perverted" and untrue. ${ }^{115}$

${ }^{111} I d$.

112 See 3 CoRBIN, supra note $2, \S 577$, at 400-02.

${ }^{113}$ See Restatement (SECOND), supra note 1, § 241, Reporter's Note.

11448 ALI Proceedings 449-50 (1971).

115 Corbin, The Interpretation of Words and the Parol Evidence Rule, 50 CoRNELL L.Q. $161,171-72$ (1965). 
The Reporter assumes, perhaps unwittingly, that the agreement has a meaning apart from the evidence used to interpret it. The pre-interpretation meaning thus would be "varied" by such interpretive evidence. Corbin clearly would charge the Reporter with interpreting the words of agreement before having considered evidence to aid that process, and would vehemently disagree that evidence introduced to interpret the terms of the parties' expression could "vary" the meaning of their expression. Prior to the introduction of evidence, the Reporter is suggesting, the only meaning the words can have is a "plain" meaning. This is an archaic standard rejected by virtually all writers, ${ }^{116}$ many courts, ${ }^{117}$ the Uniform Commercial Code, ${ }^{118}$ and even the Restatement (Second) itself. ${ }^{119}$ With more time for reflection the Reporter probably would have modified it in accordance with the Corbin position.

\section{b. The Scope Test}

Section 239(2) states the effect of a binding, completely integrated writing: prior agreements are discharged to the extent they are within its scope. ${ }^{120}$ Parties to a contract clearly may agree that not even prior consistent additional terms are part of their agreement. A partially integrated writing precludes only prior inconsistent terms. ${ }^{121}$ The structure of sections $239(1)$ and (2) is similar to that of the Uniform Commercial Code's parol evidence sections, with the qualification that under the Restatement (Second) a completely integrated agreement discharges consistent additional terms only to the extent they are "within the scope" of the completely integrated agreement. This qualification is at best amorphous, leading one to seek assistance in the comments, illustrations, and Reporter's Note.

Comment $c$ to section 239 restates the qualification: in addition to finding that there is an integrated agreement and that it is completely integrated, the court must determine that the prior consistent terms are "within the scope of the [completely] inte-

${ }^{116}$ See, e.g., 3 Corbin, supra note 2 , 542 ; MURRaY, supra note 1 , § 110; 4 Williston, supra note $2, \S 609$.

${ }_{117}$ See, e.g., Hohenstein v. S.M.H. Trading Corp., 382 F.2d 530, 531-32 (5th Cir. 1967): Pacific Gas \& Elec. Co. v. G.W. Thomas Drayage \& Rigging Co., 69 Cal.2d 33, 36-37, 442 P.2d 641, 643-44, 69 Cal. Rptr. 561, 563-64 (1968).

118 UNiform CoMmercial Code $\$ 2-202$, Comment $1(\mathrm{~b})$.

${ }^{119}$ See Restatement (SECOND), supra note $1, \S 227$, comments $a \& b$.

120 Id. § 239.

121 Uniform Commercial. Code $\$ 2-202$. 
grated agreement."122 "All relevant evidence" is to be considered in making this determination, and interpretation of both the integrated agreement and the prior agreement is required. Illustration three, which follows the "scope" comment, is based on Hayden v. Hoadley: ${ }^{123}$

In May A and B exchange properties and agree orally that $A$ will make certain repairs on the property to be conveyed by $\mathrm{A}$ to $\mathrm{B}$, the repairs to be finished by October 1. A and B then draw up and sign a memorandum of the repair agreement, specifying all the terms except that the memorandum is silent as to time of performance. If the memorandum is a binding completely integrated agreement, the agreement to finish by October 1 is discharged, and the repairs are to be finished within a reasonable time. The oral agreement as to October 1 may be relevant evidence as to what is a reasonable time. ${ }^{124}$

The phrase "[i]f the memorandum is a binding completely integrated agreement" is curious. There is a substantial question whether a memorandum that omits a term such as the time for performance can be a completely integrated agreement. The use of the illustration and the holding of the case indicate an affirmative response. Professor Corbin not only disagrees conceptually but also insists that the weight of authority is opposed to this position. ${ }^{125}$ It is difficult to quarrel with Corbin's view that judicial gap-fillers, such as a reasonable-time term, do not constitute any part of the "integration" that is supposedly protected by the parol evidence rule. ${ }^{\mathbf{1 2 6}}$ That the writing is not integrated with respect to such omitted terms may be shown by what amounts to a negative "appearance" test. The matter is simply not mentioned in the writing and, using the Wigmore aid, ${ }^{127}$ the evidence is presumably admissible because it neither contradicts, varies, nor adds to the terms of the writing. The burden is still on the proponent of the time agreement to prove it sufficiently.

122 Restatement (Second), supra note $1, \S 239$, comment $c$.

12394 Vt. 345, 111 A. 343 (1920).

124 Restatement (SECOND), supra note $1, \S 239$, illustration 3.

${ }^{125}$ See 3 CoRBin, supra note 2 , § 593, at 556-67 ("By the weight of authority, supported by the better reason, oral testimony is admissible to prove that a time or place was agreed on and to rebut the usual presumptions and inferences that would otherwise prevail.").

${ }^{126} I d . \S 593$.

1279 WIGMORE, supra note $32, \S 2430$. 
The writing is, at best, partially integrated with respect to the terms contained therein. If the Restatement (Second) had rejected the rationale and holding of Hayden $v$. Hoadley one of the boundaries of the "scope" of the integrated agreement would thereby have been clearly identified. As interpreted by illustration three, the Hayden doctrine is conceptually deficient and does not clarify the meaning and application of the "scope" concept. The other illustration $^{128}$ is somewhat more helpful, though the facts seem to indicate that the writing is only partially integrated so that consistent additional terms would have been admissible anyway. This amounts to nothing more than a statement that consistent additional terms are not discharged if the agreement is partially integrated but that they are discharged if the agreement is completely integrated. Because the "scope" qualification is unnecessary to arrive at this analysis, how does the qualification operate to permit evidence of consistent additional terms not within the scope of the completely integrated writing to be considered as part of the agreement?

\section{The Natural Omission Test}

There is a hint in the Reporter's Note to section 239 that "scope" really refers to the Williston test. ${ }^{129}$ Though following a "But cf.," the Reporter paraphrases language from the wellknown case of Mitchill v. Lath:130 "[P]rior oral agreement discharged if parties would 'ordinarily be expected to embody' it in the writing." 131 Reinforcing this hint is section 239(2)'s companion section, section 242, subsection 2(b) of which clearly sets forth the Williston test for admissibility of consistent additional terms. ${ }^{132}$ Section 242 precludes evidence of consistent additional terms when the binding agreement is completely integrated (the evidentiary consequence of section 239(2)) but adds:

An agreement is not completely integrated if the writing omits a consistent additional agreed term which is

(a) agreed to for separate consideration, or

(b) such a term as in the circumstances might naturally be omitted from the writing. ${ }^{133}$

\footnotetext{
128 Restatement (Second), supra note 1, \$239, illustration 4.

1294 WILLISTON, supra note 2 , $\$ 638$.

130247 N.Y. $377,381,160$ N.E. 646,647 (1928).

131 Restatement (SECOND), supra note $1, \S 239$, Reporter's Note to comment $c$.

${ }^{132}$ Id. \$§ 239, 242.

${ }^{133}$ Id. § 242(2).
} 
Subsection 2(a) is consistent with case law, which allows proof of consistent agreements not evidenced by the writing where there is separate consideration for the consistent additional term. ${ }^{134}$ Subsection 2(b) is the Williston test, and the Reporter was well aware of the acceptance of the Williston test at this point and of the concomitant rejection of any Corbin opposition thereto. ${ }^{135}$ Furthermore, the Reporter illustrates this use of the Williston test by reviewing the four-to-three holding in Mitchill $v$. Lath ${ }^{136}$ which he accurately indicates is a prime illustration of the "naturally omitted" criterion. ${ }^{137}$ The extrinsic agreement in that case provided for removal of an unsightly icehouse, allegedly as part of a total agreement to purchase real estate. The question that divided the court was whether parties, situated as were these, might naturally and normally include the icehouse agreement in the writing; the majority held that such parties would, and therefore excluded the evidence of this prior oral agreement. As suggested by the Reporter, both the majority and the dissenters accepted the "naturally omitted" principle, ${ }^{138}$ disagreeing only as to its application.

Comments $c$ and $d$ to section 242 are of some value in determining the operation of the "scope" qualification to section 239(2). ${ }^{139}$ Comment $c$ notes that subsection 2(a) of section 242 may be regarded as a species of subsection 2(b), the generic "natural omission" test. The great difficulty in reconciling section 242(2) with section 239(2) is the statement in section 242(2) that a consistent additional term that is naturally omitted or specifically agreed to for a separate consideration (and, therefore, naturally omitted) results in a determination that the "agreement is not completely integrated." Section 239(2) deals exclusively with completely integrated agreements and discharges any consistent additional term within the scope of such an agreement. To determine whether a consistent additional term is within the scope of the completely integrated agreement, the test that cries out for recognition is the "natural omission" test: If a consistent additional term is omitted from the writing but is of the kind

${ }^{134}$ See, e.g., Armstrong v. Cavanagh, 183 Iowa 140, 166 N.W. 673 (1918); Sermuks v. Automatic Aluminum Heel Co., 256 Mass. 478, 153 N.E. 8 (1926).

${ }^{135}$ See 48 ALI Proceedings 454-55 (1971).

136247 N.Y. 377,160 N.E. 646 (1928).

13748 ALI ProceEdings 455 (1971).

${ }^{138}$ See Mitchill v. Lath, 247 N.Y. 377, 160 N.E. 646 (1928).

139 RestatemeNt (SECoND), supra note $1, \S 242$, comments $c$ \& $d$. 
reasonable parties might naturally omit, the consistent additional term is not within the scope of the completely integrated agreement. Section 242(2) does not permit this analysis, however, because it clearly indicates that an agreement is not completely integrated if the writing omits a consistent additional term that parties might naturally omit. Thus, if a naturally omitted consistent additional term is proved, under section 242(2) the agreement can only be partially integrated and the consistent additional term is admissible. The Restatement (Second), therefore, leaves a conceptual void in section 239(2). A consistent additional term outside the scope of the completely integrated agreement cannot be a term that is naturally omitted from the writing; if it is, then the writing is only partially integrated. Thus the unanswered question remains: What is a consistent additional term outside the scope of the completely integrated agreement?

Because the question is not expressly considered in the $R e$ statement (Second), it is appropriate to consider the apparent goals sought to be achieved through these sections. If the parties to a contract have reduced even part of their agreement to writing with the intention that such part be evidenced exclusively by the writing, the writing is partially integrated and no contradiction of the writing will be permitted. ${ }^{140}$ Because they did not intend to state their entire agreement in writing, additional terms consistent with their partially integrated writing should be provable. If, however, the parties intended to reduce their entire agreement to writing, neither party should be faced with the necessity of litigating an alleged prior agreement not evidenced by the writing even though that agreement is not inconsistent with the terms of the writing. ${ }^{141}$ Thus the parties should be able to agree that the writing is complete and final, and that intention should be enforced. Both the Restatement (Second) and the Uniform Commercial Code deal with these purposes as the foregoing analysis suggests, ${ }^{142}$ but each also admits the possibility that there may be some kinds of consistent additional terms which the parties would not naturally include in the most complete writing of their agreement. They therefore recognize two types of consistent additional terms: (a) those the parties would naturally in-

${ }^{140}$ See 3 Corbin, supra note $2, \S 581 ; 4$ Williston, supra note $2, \S 633$.

141 See 3 Corbin, supra note 2, \$576; 4 WILliston, supra note $2, \S 631$.

${ }^{142}$ See RestatemeNt (SECOND), supra note $1, \S 235$ \& comment $b$; UNiform Commercial Code $\$ 2-202$. 
clude in the writing, and (b) those the parties would naturally omit from the writing. Once it is recognized that parties might have a prior agreement that they would not naturally include in the writing, the inevitable conclusion is that evidence of such consistent additional terms must be admitted to give the proponent the opportunity to prove that such a consistent additional agreement was made. Thus the consistent additional terms in (a) will be excluded while those in (b) will be admitted.

The U.C.C. formulation does not deal with this matter at all in the section language. ${ }^{143}$ Section 2-202 merely distinguishes final expressions from complete and exclusive expressions of agreement. The former preclude contradictory terms and the latter preclude even consistent additional terms. The section language stops at this point; however, a comment does confront the problem: "If the [consistent] additional terms are such that, if agreed upon, they would certainly have been included in the document in the view of the court, then evidence of their alleged making must be kept from the trier of fact."144

This is the Williston test in a different garb. "Would certainly" can be reasonably interpreted to mean that which reasonable parties would naturally and normally include in the writing. Suppose the terms are such that they would not certainly have been included in the document? The proponent of such extrinsic terms is then permitted to introduce evidence of their existence and to attempt to convince the trier of fact that such a prior agreement was made. If the terms are of a type that would certainly be included in the document, they are inadmissible if the parties intended the document to be a complete and final statement of their agreement. The Restatement (Second), following the thrust of the original Restatement's section 240, describes the circumstance in which such consistent additional terms might naturally be omitted from an otherwise final and complete document as follows:

This situation is especially likely to arise when the writing is in a standardized form which does not lend itself to the insertion of additional terms. Thus agreements collateral to a negotiable instrument if written on the instrument might destroy its negotiability or otherwise make it less acceptable to third parties; the instrument 
may not have space for the additional term. Leases and conveyances are also often in a standard form which lead naturally to the omission of terms which are not standard. These examples are not exclusive. . . Even though the admission does not seem natural, evidence of the consistent additional term is admissible unless the court finds that the writing was intended as a complete and exclusive statement of the terms of the agreement. ${ }^{145}$

The last sentence of the comment was emphasized to focus on the apparent contradiction. The only preclusion to the admission of evidence of consistent additional terms occurs when the parties intend their writing as complete and exclusive. Indeed, when the determination is made that the writing is final but incomplete, it is an inescapable conclusion that some consistent additional terms would naturally be omitted. Can one similarly conclude, however, that all consistent additional terms would necessarily be included in a complete, final, and exclusive writing? Section $239(2)^{146}$ clearly implies that it is possible to have a completely integrated agreement and still permit evidence of consistent additional terms that would be naturally omitted from the writing because not within its scope. On the other hand, section $242(2)^{147}$ indicates that proof of such naturally omitted terms precludes any possibility of determining that the writing is completely integrated. Again the comment to section 242 fudges the situation by indicating that once it is determined that certain consistent additional terms were naturally omitted from the writing, " $[I] \mathrm{t}$ is not necessary to consider further ... whether the agreement is completely integrated . . . ."148

The Restatement (Second) suggests both answers to the same question because (1) it maintains a distinction between the effects of a final writing, which will preclude evidence of inconsistent additional terms, and of a complete and final writing, which will preclude evidence of any additional terms - the same distinction set forth in the U.C.C.- -at the same time that it (2) perpetuates the Williston belief, also embodied in the U.C.C., that there are some kinds of consistent additional terms-those naturally

145 Restatement (Second), supra note $1, \$ 242$, comment $d$ (emphasis supplied).

${ }^{146}$ Id. $\S 239(2)$ ("A binding completely integrated agreement discharges prior agreements to the extent that they are within its scope.").

${ }_{147}$ Id. $\$ 242(2)$.

${ }^{148} I d . \S 242$, comment $d$. 
omitted-that should be provable even when the writing is not only final but final and complete. It is plausible to suggest that a writing is not final and complete if certain terms would naturally be omitted therefrom; hence section 242(2). But to maintain a distinction between merely final writings on the one hand and final and complete writings on the other, section 239(2) contemplates a completely integrated agreement that would admit only such consistent additional terms as are "within the scope" of the complete and exclusive statement of the parties' agreement. It is the Williston position that causes the problem. In defense of the Restatement (Second), not only is the "natural omission" test set forth in the original Restatement ${ }^{\mathbf{1 4 9}}$ and repeated in the Code comment; ${ }^{150}$ it is also supported by a considerable body of case law. ${ }^{151}$ Thus its deletion from the draft of the Restatement (Second) would have been unacceptable in terms of the overriding purpose of a restatement. In addition, there are lawyers, apparently including the Reporter, who see merit in a continuation of this test. ${ }^{152}$ Yet it is fair to suggest that the test will operate to permit evidence of consistent additional terms in the face of what appears to be a complete and final statement of the parties' agreement only where the terms are clearly the kind that the parties would not have included in the document. In this light, the language of the Code comment ("would certainly") appears more apt than the "naturally omitted" phraseology of the Restatement (Second). There are undoubtedly myriad drafting approaches the Restatement (Second) could have pursued; one approach, which would have avoided the present confusion, is found in my hypothetical drafts of sections 239(2) and 242(2):

Section 239(2): A binding completely integrated agreement discharges prior agreements to the extent that they would naturally [or "would certainly"] have been included in such a completely integrated agreement.

Section 242(2): A completely integrated agreement does not preclude evidence of a consistent additional agreed term which is

(a) agreed to for separate consideration, or

(b) such a term as in the circumstances might naturally be omitted from the writing.

\footnotetext{
149 Restatement of Contracts $\$ 237$ (1932).

150 UNIFORM COMMERCIAL CODE $\$ 2-202$, Comment 3.

${ }^{151}$ See 3 CoRBin, supra note $2, \S 583$, at $471-74 \mathrm{n} .92$, and cases cited therein.

${ }^{152}$ See 48 ALI Proceedings 455 (1971).
} 
These suggested drafts are anything but ideal. Drafts more closely conforming to my analysis would necessitate the redrafting and restructuring of virtually all sections in topic three of chapter nine. Distinctions between the agreement and the writing evidencing the agreement should, among other changes, be stressed throughout topic three, paralleling the distinction found in the U.C.C. version of the rule. ${ }^{153}$ The suggested drafts of sections 239(2) and 242(2) are submitted for two reasons: (1) they do no violence to the overall structure of topic three and the modifications of language are easily accomplished; (2) more importantly, they set forth more precisely, and without ambiguity or contradiction, the apparent intention of the Reporter and those who assisted him in preparing these subsections. The drafts permit the continued distinction between the effect of a final but incomplete (partially integrated) writing and that of a final and complete (completely integrated) writing. As the Reporter recognized, this distinction is critical. ${ }^{154}$ Simultaneously, these drafts allow application of the Williston test in the peripheral area of consistent additional terms that would certainly or naturally be omitted from the completely integrated writing, thus appeasing those who favor the Williston test, reflecting the case law applying it, and maintaining symmetry with the U.C.C. statement. At the same time, the drafts would do little violence to the overall Corbin flavor of the Restatement (Second).

\section{Standardized Agreements}

\section{A. The Underlying Problem}

Section 237 of the Restatement (Second) has no antecedent in the original Restatement, though some relation to the old section 70 may be inferred. ${ }^{155}$ Captioned "Standardized Agreements," section 237 is a reaction to the massive use of standardized, printed forms or "pad" documents evidencing a contract. ${ }^{156}$ It is an essential section within topic three because any exploration of the effects of adopting a writing should include consideration of

153 UNiform COMMercial CODE $\S 2-202$.

${ }^{134}$ See Restatexent (Second), supra note 1, \& 242, Reporter's Note.

155 See RestateneNt of CoNtracts $\$ 70$ (1932) ("One who makes a written offer which is accepted, or who manifests acceptance of the terms of a writing which he should reasonably understand to be an offer or proposed contract, is bound by the contract, though ignorant of the terms of the writing or of its proper interpretation.").

156 Restatement (SecoND), supra note 1, \$ 237. 
the adoption of standarized writings. There is, moreover, an intimate relationship between section 237 and the doctrine of unconscionability: ${ }^{157}$ section 234 is mentioned in two of the comments to section $237^{158}$ and there is a clear recognition of this relationship in the 1970 Proceedings. ${ }^{159}$ Thus a complete analysis of section 237 would require an equally complete analysis of the doctrine of unconscionability as set forth in section 234 and of the relationship between the two sections. Such an investigation deserves separate inquiry and is beyond the scope of this Article. Any discussion of topic three, however, cannot omit an exploration of the more troublesome aspects of this new section.

The underlying problem confronted by section 237 is suggested in comment $b$ : "A party who makes regular use of a standardized form of agreement does not ordinarily expect his customers to understand or even to read the standard terms." If it is not reasonable to expect parties to understand or even to read such boilerplate, the question arises whether parties are bound by the terms found in such standardized documents. Beyond the fact that the printed form is typically neither understood nor even read, certain other facts are also unassailable. Standardized writings are here to stay, their utility is much admired, and they are essential to our complicated exchange society. ${ }^{160}$ The question to be confronted is this: How should the law react to writings, allegedly evidencing contracts, that will continue to be used but will not be understood or even read? If the certainty and stability of written manifestations of agreement are to be maintained-if "contracts" are to be worth the proverbial paper on which they are written-parties must be bound by what they sign, even if what they sign is a standardized writing they neither understood nor read. Yet the writing has never been anything more than evidence of the agreement; ${ }^{161}$ a fortiori, if the writing is normally executed absent understanding of its fine print provisions, it is less worthy as evidence of the true agreement. Much of the underlying philosophy of article two of the Uniform Commercial Code can be understood on this basis.

${ }^{157} \mathrm{Id}$. $\S 234$.

${ }^{158}$ Id. $\$ 237$, comments $c \& f$.

15947 ALI Proceedings 523-24 (1970).

${ }^{160}$ See Murray, Intention over Terms: An Exploration of UCC 2-207 and New Section 60, Restatement of Contracts, 37 Ford. L. REv. 317 (1969).

161 See text accompanying notes 1-4 supra. 
The Code section dealing with unconscionability, based upon the need for preventing "unfair surprise," is an obvious manifestation of this philosophy. ${ }^{162}$ A less obvious but still clear manifestation can be seen in the controversial section dealing with the "battle of the forms," 163 as well as in the sections on disclaimer of express warranties, ${ }^{164}$ on limitation of remedies, ${ }^{165}$ and even in the generic provisions on contract formation. ${ }^{166}$ All of these sections can be analyzed, in terms of the principal thrust of article two, as attempts to achieve a more precise and fair identification of the actual or presumed assent of the parties-a process that requires an emphatic understanding that the writing evidencing the agreement is only evidence of that assent. ${ }^{167}$

Standardized writings are particularly suspect in identifying the true intent of the parties. Absent an understanding of most boilerplate provisions, as Llewellyn recognized, there can be no conscious assent to such terms. Conscious assent can be given only to "dickered" terms, the terms reasonable parties normally and consciously negotiate. As to the boilerplate, "blanket assent" may be presumed as to any "decent" terms; but such "blanket assent" will not be presumed as to "indecent" or, in the language of the Restatement (Second), "bizarre or oppressive" boilerplate provisions. ${ }^{168}$

\section{B. Reasonable Expectations of the Assenting Party}

The Restatement (Second) attempts to unify these difficult concepts in section 237. Subsection one contains a qualified statement of the general rule that a party is bound by what he signs. The qualification is substantial: "[W]here a party to an agreement signs or otherwise manifests assent to a writing and has reason to believe that like writings are regularly used to embody terms of agreements of the same type ..."169 The focus here is on the signer, the party assenting to the standardized agreement. If that party signs a standard form document, and if he should understand the document to be typical of those used in the kind of transaction involved, he is said to have adopted as an integrated

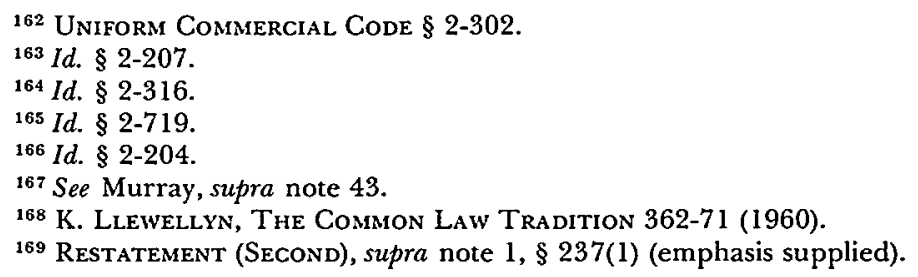


writing the standard printed terms which he has neither read nor understood. There is little discussion of subsection one in the Proceedings, the Reporter having been anxious to move on to subsection three. ${ }^{170}$ The Reporter did note, somewhat facetiously, that he had "stated first a rather reactionary proposition, which is subsection (1); that is, when you agree to a standard agreement, you agree to it, and that means everything that's in it, subject, of course, to qualifying terms." 171 This leaves some ambiguity as to the intention of the draftsman in relation to the qualification. Presumably the required showing is that the assenting party reasonably understood the form agreement to be the kind typically used in like transactions. As to consumers, it might be difficult to show that such a reasonable belief existed in certain transactions. The qualification could, however, explain the underlying philosophy of the section: If the assenting party has reason to believe that the standard form that he is signing is the typical standard form used in such transactions, he is assenting only to that which is typically found in such forms and not to any "indecent," "oppressive," or "bizarre" terms that might be included therein. ${ }^{172}$ Only the typical (or standard) terms are adopted by the assenting party as his integrated agreement. If this analysis is plausible, it suggests some interesting possibilities.

Consider, for example, a party supplied with a standard form that, without his reading or understanding it, appears to be the same kind of form he and others similarly situated have signed in similar past transactions. With reason to believe he is signing the usual form, the party signs a document containing in fine print unusual provisions he had no reason to believe were included. An example of such a bizarre term, suggested in an earlier exploration of the same concept, ${ }^{173}$ may, though seemingly absurd, help to clarify the concept. Assume a contract for the sale of a new automobile evidenced by what appears to be the standard printed form but which contains an unnoticed boilerplate provision:

The parties hereby agree that if, during the first year of operation of this automobile, the automobile is operated

170 See 47 All Proceedings 525 (1970).

${ }^{171} I d .524$.

${ }^{172}$ See Restatement (Second), supra note $1, \S 237$, comment $f$; K. Llewellyn, supra note 168 , at 370 .

${ }^{173}$ See, e.g., MURRay, supra note 1 , § 353; Murray, supra note 43. 
on any Tuesday afternoon by a party wearing a red necktie, all rights in the automobile will be forfeited by the owner and ownership of the automobile will revert to the seller.

It cannot be gainsaid that prior to the Uniform Commercial Code and the Restatement (Second) even the most literal-minded court would have refused to enforce this provision. Myriad conclusory reasons might have been stated for such a refusal, including a "shock the conscience" or "public policy" test; the principle that "the law abhors forfeitures"; and even more traditional "covert tools" such as a "failure of consideration" test. ${ }^{174}$ A few courts might simply have found that assent was lacking. There is precedent for refusing to bind a party by unexpected provisions inconspicuously inserted in a standard form. ${ }^{175}$ Assuming the applicability of the Uniform Commercial Code to such a case today, it would be appropriate to fit the holding and rationale under the rubric of unconscionability as set forth in section 2-302. While admitting the imperfections of a statutory approach to such problems, Llewellyn would thus excise "indecent" provisions from sale-of-goods contracts. ${ }^{176}$

The determination of unconscionability depends, essentially, upon a finding of a lack of assent. ${ }^{177}$ Assent may be lacking either because a party was reasonably unaware of an unexpected, material risk-shifting provision which he did not read, or because he could not have understood the provision had he read it. If, however, such a provision were made clear, either by redrafting it in comprehensible form or by explaining the provision prior to the signing, assent may still be lacking because awareness alone does not supply assent. Section 237 is not addressed to the "contract of adhesion" (a phrase eschewed by the Restatement (Second)), ${ }^{\mathbf{1 7 8}}$ in which one party must adhere to the terms of a contract dictated to him by a party with awesome bargaining power; it is apparently designed to deal exclusively with lack of assent arising from inclusion in the printed form of unexpected, bizarre, oppressive, or "indecent" provisions of

${ }^{174}$ See MurRay, supra note $1, \S 354$, and cases cited therein.

${ }^{175}$ Cutler Corp. v. Latshaw, 374 Pa. 1, 97 A.2d 234 (1953).

176 K. LLEWELLYN, supra note 168 , at 362-71.

17 See generally Murray, supra note 43.

${ }^{178}$ See Restatement (SecoNd), supra note 1 , $\$ 237$, comment $f$; Murray, supra note $1, \S 350$. 
which the signer would not reasonably be aware. Presumably the lack of assent due to a "take it or leave it" imposition of oppressive terms is to be considered exclusively under the unconscionability section, section 234 . This is made reasonably clear in comment $c$ to section 237, wherein section 234 is mentioned as an example of how standard terms may be superseded for reasons other than those set forth in section 237:

The obvious danger of overreaching has resulted in government regulation of insurance policies, bills of lading, retail installment sales, small loans, and other particular types of contracts. Regulation sometimes includes administrative review of standard terms, or even prescription of terms. Apart from such regulation, standard terms imposed by one party are enforced. But standard terms may be superseded by separately negotiated or added terms (§229), they are construed against the draftsman (\$232), and they are subject to the overriding obligation of good faith $(\$ 231)$ and to the power of the court to refuse to enforce an unconscionable contract or term (§ 234). Moreover, various contracts and terms are against public policy and unenforceable. ${ }^{179}$

The emphasized sentence is curious but may suggest that, apart from such regulation, the general rule is that standard terms are enforced except when, inter alia, they are determined to be unconscionable. The general rule is also qualified by section 237 itself: Even if a term is not unconscionable and is not subject to judicial excision through separately negotiated or added terms, construction against the draftsman, a finding of bad faith, or a determination that enforcement would be against public policy, a party may still escape from the provision if, because it was outside the scope of what he would reasonably expect to find in a standardized writing evidencing the particular transaction, the party cannot be said to have assented to the provision. ${ }^{180}$

\section{The Reasonable Expectations of the Other Party}

The test for determining whether a term is outside the scope of terms that could reasonably be expected to be included in a typical printed form is found in subsection three. Unlike

${ }^{179}$ Restatement (SECOND), supra note $1, \S 237$, comment $c$ (emphasis supplied).

${ }^{180} \mathrm{Id}$. $\$ 237$. 
subsection one, where the emphasis was upon the assenting party's "reason to believe," the test in subsection three focuses upon what the other party had reason to believe: "Where the other party has reason to believe that the party manifesting such assent would not do so if he knew that the writing contained a particular term, the term is not part of the agreement."181

A number of noteworthy implications can be drawn from this language. The current draft is a modification of section $237(3)$ as it originally appeared in the Fifth Tentative Draft: "Where the other party has reason to know that the party manifesting such assent believes or assumes that the writing does not contain a particular term, the term is not part of the agreement." 182

Professor Farnsworth was troubled by the change from this original draft to the current subsection:

I am not sure but what [Reporter Braucher] gave up too easily on [his] original language. I'm troubled by the apparently simple form that contains a clause in the back of it, perhaps a more or less innocuous clause, but one which, it turns out, because of later events, is important to the party signing. It is quite possible . . that under Mr. Willard's language it would not be clear that he would not have signed the agreement had he known that this clause was added; and yet under your original language it would not be a part of the contract. ${ }^{183}$

The Reporter responded:

As I read Mr. Willard's formulation, it doesn't require the impossible showing of what the party would have done if. What it requires is that the stronger party, who submits the adhesion contract or prepares the standard form, have reason to believe that the party would not assent if he knew about this. I think it's an impossible burden of proof to put on somebody that he would have refused to sign if he had known about this. All this requires is that there be reason to believe that that's so. If so, the obvious remedy is to flag it in some way. ${ }^{184}$

${ }^{181}$ Id. § 237(3); cf. id. § 237(1).

182 Restatement (SeCOND) OF Contracts \& 237(3) (Tent. Draft No. 5, 1970).

18347 ALI Proceedings 527-28 (1970). The change of language was pruposed by Charles Willard of New York. See id. 525.

${ }^{184}$ Id. 528. 
Professor Farnsworth suggested the "now out of date example" of the bank signature card containing on the back a clause dealing with stop payment orders. Applying the Willard formulation of section 237(3), the clause would be part of the agreement; but under the original (Braucher) draft it would not. Professor Farnsworth concluded: "[A]ssuming this is a clause which the party signing would not be expected to come across . . . your original rule is a better rule." 185

Mr. Willard then intervened:

I think the answer may be, sir, that many of us have signed contracts containing provisions that we wish weren't in there, but on balance we thought: All right, we want the contract, and we have to take the good with the bad. And I want to make it as clear as I can that when you get into the area of unconscionability, then you are under $\S 234 .{ }^{186}$

This was immediately followed by further explanation from the Reporter, who illustrated the point by referring to a case involving a bank signature card containing a provision that manifests the signer's agreement to waive a jury trial. ${ }^{187}$ Recalling the holding of the appellate court that the clause was not unconscionable, the Reporter stated:

Whether it's unconscionable or not seems to me to depend on a whole series of value judgments that I wasn't able to get enough certainty on to include here, but I would hate to have that turn on the question whether the party assumed that there was no such waiver. Assuming it's a perfectly legible provision and it has not been concealed in any way and he signs the card, and there it is, it seems to me the proper thing to pay attention to is whether the clause is oppressive in some way, and not this notion that it's unexpected at that point.

I think the same thing would go for the stop payment clause, that most of the cases that threw out the stop payment disclaimer of liability on the part of the bank did so on the direct ground that it either was without consideration or it was against public policy,

${ }_{187}$ David v. Manufacturers Hanover Trust Co., 55 Misc. 2d 1080, 287 N.Y.S.2d 503 (N.Y. Civ. Ct. 1968), rev'd, 59 Misc. 2d 248, 298 N.Y.S.2d 847 (Sup. Ct. 1969) (per curiam). 
and not on the ground that it hadn't been agreed to; and that's what I think we're talking about here. ${ }^{188}$

Professor Farnsworth's statements ${ }^{189}$ suggest a workable rule: If the clause or term in the standard form is one the signing party would not reasonably expect to be included, he will not be said to have assented to it and, therefore, it will not be part of the agreement. The original (Braucher) draft of section $237(3)^{190}$ can be so interpreted. If the signing party would not reasonably expect the term to be part of the form, the other party would have reason to know that the signer believed or assumed that the writing did not contain that particular term. The ultimate criterion appears to be whether the signer as a reasonable party under all of the circumstances would have expected such a term in the printed form. Thus even under the Braucher draft, which Farnsworth prefers, one may wonder why the test was not simply stated in terms of the reasonable expectations of the signer. Wonder aside, the Braucher test can be made workable. The Willard test, however, is substantially different and much more difficult to apply.

One interpretation of this test (the present version of section $237(3)$ ) is that it simply requires a finding that the assenting party would not have signed if he had known of the term in the printed form. As the Reporter emphasizes in his first response to Farnsworth, ${ }^{191}$ this is incorrect. Such a showing would be impossible, and if submitted to a jury as a question of fact, could result in a rewriting of the "contract" to satisfy the proclivities of the trier of fact. Rather, the test is whether the "stronger party, who submits the adhesion contract or prepares the standard form, has reason to believe that the party would not assent if he knew about this." The Reporter's choice of language is fascinating. He obviously contemplates a "stronger party"--one who dictates an "adhesion contract" and thus has the superior bargaining position that permits such compulsion. With that kind of awesome bargaining power, what difference does it make whether the signer knows of the term? If he has no choice, if he must adhere, he does not assent to the oppressive term whether he knows of it

\footnotetext{
18847 ALI ProcendiNgs 529 (1970).

189 Text accompanying notes 183 \& 185 supra.

190 Text accompanying note 182 supra.

191 Text accompanying note 184 supra.
} 
or not. If he has not truly assented to an oppressive term, quaere: is the term unenforceable because it is unconscionable?

The confusion of concepts is further demonstrated by the remainder of the Reporter's first response to Farnsworth ${ }^{192}$ and by comment language to the adopted (Willard) draft. The only requirement is that the nonsigning party have "reason to believe" the assenting party would not have signed had he known of the term. But when would the nonsigner have such "reason to believe"? Comment $f$ to section 237 contains the following explanation: "Reason to believe may be inferred from the fact that the term is bizarre or oppressive, from the fact that it eviscerates the non-standard terms explicitly agreed to, or from the fact that it eliminates the dominant purpose of the transaction." Suppose the form contains such a "bizarre or oppressive" term-the kind of term the nonsigner would have reason to believe the other party would not assent to if he knew about it. How does the nonsigner ascertain that that term becomes part of the agreement? The Reporter's response is simple: "[T] he obvious remedy is to flag it in some way." 193 This suggests that the term be made conspicuous-that it be "brought home" to the assenting party. Suppose it is "brought home" or "flagged." If the signer is not forced to adhere to the term-that is, if he can procure the goods or services elsewhere without the term-presumably he will not sign. If the signer is not forced to adhere, the nonsigner does not have superior bargaining power. $\mathrm{He}$ is not the "stronger party" and has not submitted an "adhesion contract." It is important to distinguish lack of assent due to a party's signing the standard form under the reasonable expectation that such a term would not be included, from lack of assent arising where the signer, whether he knew of the term or not, would sign because he had no choice.

Willard's reply is difficult to comprehend. ${ }^{194} \mathrm{He}$ appears to be addressing the situation in which the "bad" term is flagged, because he contemplates a signer who "thought" he had to take the good with the bad and thus signed knowing that the "bad" term was included. Under Willard's version of section 237(3) the signer is bound, but the term is presumably still subject to excision under the unconscionability section, section 234 .

192 Id.

${ }^{193}$ See id.

194 Text accompanying note 186 supra. 
The Reporter's response to Willard is again confusing. ${ }^{195}$ As to the waiver-of-jury provision illustration, he seems to be saying that a legible, non-concealed version of this provision cannot be characterized as "unexpected" and, therefore, that section 237(3) would not apply to it. Rather, it would be proper "to pay attention to ... whether the clause is oppressive in some way ...." If it were oppressive, then might it be excised under section 234 as unconscionable? As suggested above, one of the facts from which "reason to believe" may be inferred under section 237(3) is that the term is "oppressive." The final paragraph of the Reporter's second response ${ }^{196}$ suggests that stop-payment clauses are to be similarly treated. He then resorts to the rationales for declaring such clauses unenforceable: lack of consideration or a finding that they are against public policy. He emphasizes that courts did not excise such clauses "on the ground that they hadn't been agreed to; and that's what I think we're talking about here." But at this point section 237(3) is concerned with what has or has not been agreed to.

The Reporter's response simply ignores the documented analysis that courts often used "covert tools" to arrive at conscionable results, an analysis recognized in the Uniform Commercial Code ${ }^{197}$ and adopted by the Restatement (Second) itself. ${ }^{198}$ One such covert tool was a finding that a required contractual element-consideration, for example-was lacking. Perhaps the ultimate covert tool was a determination that the clause violated that ineffable standard of "public policy." The fact is that if waiver-of-jury or stop-payment clauses would not be expected by the reasonable party asked to sign the signature card, then they have not been assented to. That such clauses are "flagged" may only mean that they are in bold or conspicuous print. Like disclosure-of-warranty clauses, exclusion-of-consequential-damages clauses, or similar "oppressive" terms, even when physically conspicuous, may still remain substantively "unflagged" since a reasonable party may not understand such terms. ${ }^{199}$ Finally, even when these clauses are physically and substantively conspicuous, the signer may have no choice as to oppressive terms if the stronger party can dictate them. In that event, the

\footnotetext{
195 Text accompanying note 188 supra.

196 Id.

197 See Uniform Commercial Code $\$ 2-302$ \& Comments.

198 See Restatement (Second), supra note 1, § 234 \& comments.

199 Murray, supra note 10 , at 4 .
} 
signer does not agree to them. Judicial findings of lack of consideration or of public policy violations are conclusory and unnecessary here, since the basic requirement of mutual assent is lacking.

The difficulty manifested in the effort of the Restatement (Second) to deal with the pervasive problem of distinguishing between binding and non-binding standard form terms should not detract from the necessity of confronting this problem. In section $237(3)$ the goal is perceptible: to prevent a party from being bound to printed terms that he would not expect to be included in the standard form. An inference may even be drawn that the draftsmen of the Restatement (Second) intended section 237(3) to include, as part of the agreement, terms that would normally be found in the standard form but which were excluded. ${ }^{200}$ This suggests that an attempt was made to state that parties are bound by what the signer reasonably expects to be included in the standardized agreement form-no more and no less. The true circle of assent is thereby identified as the parties' reasonable expectations of the terms evidencing their agreement, regardless of the actual terms in the printed form. Section 237 is nothing more than an effort to deal with a species of unconscionability. It may be desirable to include it as a separate section. Its placement in juxtaposition to section 234, however, would not only have been natural but would also have relieved much of the concern manifested in the Proceedings. ${ }^{201}$ More importantly, the recognition that the underlying question in both areas is one of assent would have remedied most of the problems already discussed.

There may be cases in which the "bad" or "oppressive" term would not have been agreed to had the signer known of it. The unrealistic example of the forfeiture of the automobile through wearing a red necktie on a certain day of the week is certainly a bizarre term that a signer would not reasonably expect to be included in the standard form. ${ }^{202}$ Since other automobile dealers do not include such terms in their forms, if the clause had been flagged (physically and substantively) the buyer presumably would not have signed but would have purchased an automobile elsewhere. Absent such complete flagging, the term should not

200 See 47 ALI Proceedings 526 (1970); text accompanying notes 182-88 supra.

${ }^{201}$ See 47 ALI Proceedings 534-35 (1970).

${ }^{202}$ See text accompanying notes 173-74 supra. 
be binding because a signer would not reasonably expect it. Similarly, illustration two to section $237^{203}$ is based on the well-known parcel check case ${ }^{204}$ wherein the small check contained "contract" terms. The terms are not part of the agreement because the bailor would not reasonably expect to find such terms on an identification ticket. As suggested elsewhere, courts sympathize with signers in such transactions and have little difficulty in holding such unexpected terms to be outside the circle of assent. ${ }^{205}$ Whether such terms could be forced upon a bailor if he had been made aware of them is another question, the resolution of which depends upon all of the surrounding circumstances.

Evidence of such surrounding circumstances is often available. Thus illustration five to the unconscionability section, section $234,{ }^{206}$ is based upon the well-known case of Williams $v$. WalkerThomas Furniture Co. ${ }^{207}$ universally considered under the rubric of unconscionability. As set forth in the illustration, the seller of retail goods knows that the buyer is a woman of limited education who, separated from her husband, supports her seven children through public assistance grants. After thirteen purchases totaling twelve hundred dollars over five years, her account balance is $\$ 164$. She purchases a stereo at $\$ 514$ and signs the retailer's standard form containing, as part of the fine print, an "add-on" clause, the effect of which is to keep a balance on each item until all items are paid for. When Mrs. Williams defaults, the retailer seeks to repossess all items sold to her over the fiveyear period. The illustration concludes that such a clause (or the entire contract) was unconscionable when made.

Even though this illustration is found in section 234 , it is possible to apply section $237(3)$ to these facts. Did the seller have reason to believe Mrs. Williams would not manifest assent if she knew the writing contained the add-on term? Probably yes under section $237(3)$ as originally drafted; Mrs. Williams would therefore not be bound by the term. The author of the modified version, however, would apparently answer the question in the negative. ${ }^{208}$ It is the kind of "bad" term that Mrs. Williams would"

203 RESTATEMENT (SECOND), supra note 1, \& 237, illustration 2.

${ }^{204}$ Klar v. H. \& M. Parcel Room, Inc., 270 App. Div. 538, 61 N.Y.S.2d 285, aff'd, 296 N.Y. 1044, 73 N.E.2d 912 (1947).

205 See, e.g., Murray, supra note 10.

206 Restatement (SECond), supra note 1, § 234, illustration 5.

207350 F.2d 445 (D.C. Cir. 1965).

${ }^{208}$ See text accompanying note 186 supra. 
prefer not to be part of the printed document, but "she would have to take the good with the bad." The term might then be excised under the rubric of unconscionability. It is possible to include as part of the other party's "reason to believe," his knowledge that he was in a bargaining position so strong as to be dictatorial. Thus he would have no reason to believe that Mrs. Williams would not assent to the oppressive term since he knew that she had no choice. The inseparability of the lack of awareness and the lack of choice, which the Restatement (Second) attempts to separate, is thus confirmed.

\section{Determining the "Circle of Assent": Unconscionability}

The unconscionability cases decided since the enactment of the Uniform Commercial Code, and even some pre-Code efforts, almost invariably involve a combination of the two elements of lack of awareness and lack of choice. ${ }^{209}$ The typical provision is either illegible or in the kind of print no one reads or understands. If the term is material and unexpected, a party should not be bound by it unless it has been brought to his attention. In the rare cases in which such a term is indeed brought to the attention of the signer, the question becomes whether real assent was manifested at that point or whether the term was forced upon the signer.

The philosophy underlying the Uniform Commercial Code is that the writing does not necessarily define the true "circle of assent." 210 One illustration of this is found in section 2-316(1) of the Code, dealing with the disclaimer of express warranties. ${ }^{211}$ Illustration eight to section 237 of the Restatement (Second) takes note of U.C.C. section 2-316(1). ${ }^{212}$ To suggest that a disclaimer of "any warranties not set forth in the documents" cannot effectively disclaim the critical specification of the goods involved is a truism: The disclaimer deals with "warranties not set forth in the documents"; but the express warranty (by description) of the specification is set forth in the documents. The disclaimer, thus, by its express terms does not apply.

There is, however, another reason why illustration eight is unfortunate. Section 2-316(1) of the Code is simply a species of

\footnotetext{
${ }^{209}$ See MURRAY, supra note $1, \S 354$, and cases cited therein.

${ }^{210}$ Murray, supra note 43, at 276.

211 UNIFORM COMMERCIAL CODE § 2-316(1).

212 Restatement (SECOND), supra note 1, § 237, illustration 8.
} 
the generic concept of assent. The same basis is found in section 2-719(2) of the Code, which prohibits a limitation or modification of Code remedies if the bargain will thus fail of its essential purpose. ${ }^{213}$ It is the "agreement in fact" that the Code seeks to protect in these and other sections: A clause disclaiming all warranties including the warranties describing the very goods which are the subject matter of the sale destroys the crucial assent of the parties. Equally absurd is a remedy clause that destroys the bargain. The parties will not be said to have assented to such clauses, regardless of the terms of the writing.

It is important to recognize that the two elements, reasonable lack of awareness of oppressive terms and lack of choice as to such terms, are recognized by the Restatement (Second) both in section 234 and in section 237. Comment $d$ to section 234 deals with "[w]eakness in the bargaining process." Listed among the factors that may contribute to a finding of unconscionability are "knowledge of the stronger party that the weaker party is unable reasonably to protect his interests by reason of physical or mental infirmities, ignorance, illiteracy or inability to understand the language of the agreement, or similar factors." ${ }^{14}$ It is here appropriate to recall the Reporter's response to Professor Farnsworth ${ }^{215}$ where he referred, in discussing section 237, to "the stronger party who submits the adhesion contract." The Restatement (Second), in elaborating the test for "reason to believe" that the signer is unaware of the oppressive or bizarre term, further evidences the commingling of section 234 and 237 concepts: "The inference is reinforced if the adhering party never had an opportunity to read the term, or if it is illegible or otherwise hidden from view. This rule is closely related to the policy against unconscionable terms . ..."216 The last remark is hardly necessary.

In addition to reconfirming the overlap between the two sections, the comments to section 234 are important in recognizing that the assent of the weaker party will be viewed under all the surrounding circumstances. Evidence of his general competency, as well as specific evidence of any physical or mental infirmities, ignorance, illiteracy, and the like, will be relevant. The "weakness" of the adhering party will be determined through

${ }^{213}$ See Uniform Commercial Code $\$ 2-719(2)$.

${ }^{214}$ Restatement (SeCond), supra note 1, $\S 234$, comment $d$ (emphasis supplied).

215 Text accompanying note 184 supra.

216 Restatement (Second), supra note $1, \S 237$, comment $f$ (emphasis supplied). 
empirical verification of the circumstances surrounding the agreement. What is unconscionable, therefore, in relation to an unskilled worker with language deficiencies may not be unconscionable in relation to a lawyer. This variable knowledge standard-what the particular party would have reason to know and understand-is desirable. It may not be relevant to choice at all, however, because the lawyer who wishes to purchase an automobile is forced to sign the same standardized form as the unskilled laborer; he derives no additional bargaining power from his knowledge of, say, the presence of warranty disclaimers in the sales agreement. Nevertheless, the factors contributing to a finding of unconscionability suggest that it will be more difficult for the lawyer to benefit from section 234 than for others with less actual or presumed knowledge. ${ }^{217}$ Nothing in section 234, unfortunately, addresses this problem; curiously, section 237(2) may be read as providing some answer.

\section{E. Equality of Treatment: The Irrelevancy of Knowledge}

"[A standardized agreement] is interpreted wherever reasonable as treating alike all of those similarly situated, without regard to their knowledge or understanding of the standard terms of the writing." 218 The Reporter regarded this subsection "as part of the law of nature," though he "found it surprisingly hard to find somebody who could formulate it."219 It stands for the proposition that

when you have a standardized agreement, one of the things about it is that it's supposed to be standard, and treat everybody the same way .... [T] $]$ he interpretation is not ... one that's personal to the particular plaintiff .. . but rather depends on the average member of the community who is likely to use this kind of agreement. $^{220}$

This is the sole elaboration of section 237(2) to be found in the Proceedings. The comment is equally frugal: "[C]ourts in construing and applying a standardized contract seek to effectuate the reasonable expectations of the average member of the public who accepts it. The result may be to give the advantage of a

\footnotetext{
${ }^{217}$ See id. $\$ 234$, comment $d$.

${ }^{218} I d$. $\S 237(2)$.

21947 ALI Proceedings 524 (1970).

220 Id. 524-25.
} 
restrictive reading to some sophisticated customers who contracted with knowledge of an ambiguity or dispute."221

The sole illustration following the comment to section 237(2) involves an exclusionary clause in an accident insurance policy and concludes that the insured is covered by the policy "without regard to his knowledge or understanding of the quoted language at the time of contracting."222 The illustration is based on Kievit v. Loyal Protective Life Insurance Co. ${ }^{223}$ and the critical language from that opinion is worthy of note:

[T] he court's goal in construing an accident insurance policy is to effectuate the reasonable expectations of the average member of the public who buys it; he may hardly be expected to draw any subtle or legalistic distinctions based on the presence or absence of the exclusionary clause for he pays premiums in the strong belief that if he sustains accidental injury which results in his disability he will be indemnified ...224

Had plaintiff been an attorney intimately acquainted with such clauses rather than a forty-eight-year-old carpenter, would the court still have regarded his actual knowledge as irrelevant and treated him identically with plaintiff Kievit? Granted, the subsection contains the qualifying phrase "wherever reasonable," providing a court with an escape hatch in such a situation; ${ }^{225}$ nevertheless, the last sentence of section 237's comment $e$ suggests that a "sophisticated customer" may be given an advantage in such a situation because the subsection directs a court to disregard special knowledge. ${ }^{226}$ Consequently, we are left with the question why a court should disregard special knowledge on the part of a particular "sophisticated customer." Why, after all, should a court refrain from considering this important circumstance under section $2 \mathfrak{3 7}$ but not under section 234 ?

There is a basis for disregarding the special knowledge of a sophisticated customer-namely, that his special knowledge, his total awareness of the standard form that he signed, did not provide him any more bargaining power than that possessed by

\footnotetext{
221 Restatement (SEcond), supra note 1 , \$ 237, comment $e$.

222 Id. \& 237, illustration 4.

22334 N.J. 475,170 A.2d 22 (1961).

${ }^{224}$ Id. at 488-89, 170 A.2d at 30 (1961).

225 See Restatement (Second), supra note $1, \S 237(2)$.

${ }^{226} I d$. $\& 237$, comment $e$.
} 
a party without such knowledge. The lawyer who under gunpoint signs a writing allegedly evidencing a contract, is well aware of the terms of the writing, but he signs anyway. Section 234 should emphatically recognize this fact; indeed, both sections should realistically consider the special circumstances affecting each signer. It is unfortunate to pretend that the signer is unaware of particular provisions in a form. It is equally unfortunate to ignore the fact that even with total understanding of the terms he may lack any bargaining power with respect to them. The confusion and misdirection caused by section 237(2), particularly in its placement in section 237 rather than in section 234 , is simply another manifestation of the general problem of the two sections: the failure to distinguish between the lack of assent due to reasonable lack of awareness and the lack of assent due to the lack of any reasonable choice.

\section{Conclusion}

The pervasive deficiency in the Restatement (Second) formulation of the parol evidence process and in its examination of standardized writings is the failure to perceive the essence of assent. The initial failure to distinguish between the agreement and the writing is a clear manifestation of the underlying conceptual error strewn throughout the parol evidence sections. A useful restatement of the parol evidence process must concentrate on the integration process and must ask the fundamental question: Did the parties intend their assent to be manifested finally, or completely and finally, by the writing evidencing their assent? This question recognizes that, though the writing may be coextensive with the agreement, it is not itself the agreement but only evidence thereof.

Similarly, a discussion of standardized agreements should recognize that the printed form itself is suspect: It may not be coextensive with the true intention of the parties. In such a case, the true intent will prevail and the printed form will be disregarded to the extent it contains terms that reasonable parties would not expect; and terms that the parties would not expect to be omitted from such a standard form will be included in the agreement if omitted from the writing. Finally, even if the form is read and the terms are totally comprehensible to the signer, he will not be bound if he had no choice as to any oppressive, material risk-shifting term. These thoughts can be gleaned-but 
only gleaned, and that only with considerable effort-from the Restatement (Second).

Other aspects of topic three of chapter nine of the Restatement (Second)-interpretation of integrated agreements, ${ }^{227}$ situations in which the parol evidence rule does not apply, ${ }^{228}$ integrated agreements subject to oral conditions, ${ }^{229}$ and untrue recitals and evidence of consideration ${ }^{230}$ - have been briefly explored elsewhere and, in any case, do not raise problems of the same magnitude as those raised by the discussion of the parol evidence process and standardized agreements. When the draftsmen of the Restatement (Second) initially directed their attention to the parol evidence process, a number of fine analyses were available, so that a better result might have been had. Perhaps my criticisms expect more of a restatement than it can reasonably deliver, given the spirit of compromise which must pervade the process. Unfortunately, however, judicial reliance on these newly stated provisions may result in absurd decisions or may lead to the conclusion that the new provisions are simply unusable. If so, then the Restatement (Second) of Contracts will have failed to provide the cohesive guidance it should, and much of its purpose will remain unfulfilled.

${ }^{228}$ Id. \$ 240.

${ }^{229}$ Id. § 243.

${ }^{230}$ Id. § 244. 